\title{
Study on the Softening Mechanism and Control of Red-Bed Soft Rock under Seawater Conditions
}

\author{
Zhen Liu ${ }^{1,2,3}$, Xinfu He ${ }^{2,3,4} \mathbb{D}^{\mathbb{D}}$, Jin Fan ${ }^{2,3,4}$ and Cuiying Zhou ${ }^{1,2,3, *}$ \\ 1 School of Civil Engineering, Sun Yat-Sen University, Zhuhai 519082, China \\ 2 Research Center for Geotechnical Engineering and Information Technology, Sun Yat-Sen University, \\ Guangzhou 510275, China \\ 3 Guangdong Engineering Research Centre for Major Infrastructures Safety, Guangzhou 510275, China \\ 4 School of Marine Sciences, Sun Yat-Sen University, Zhuhai 519082, China \\ * Correspondence: zhoucy@mail.sysu.edu.cn
}

Received: 22 June 2019; Accepted: 18 July 2019; Published: 21 July 2019

\begin{abstract}
Red-bed soft rock easily softens and disintegrates when it comes into contact with water, which is the main factor restricting the application of soft rock as an engineering filler. Therefore, research on the influence of seawater on soft rock softening has great significance for the application of soft rock in marine engineering. To examine the softening mechanism of soft rock under seawater conditions, two kinds of soft rock softening experiments, as well as ion inhibition tests of soft rock softening, were performed under seawater and pure water conditions, and the results were compared. The variation in the soft rock composition, the deformation and failure characteristics of soft rock under the influence of sea water, and the variation in main cations in the softening process of soft rock are examined successively; the influences of different ions on soft rock softening are further analysed. Based on the analyses, the softening mechanism and control method of soft rock under sea water conditions are expounded. The study showed that soft rock softening was inhibited by seawater, which decreased the softening degree of soft rock. The main cations in seawater had an inhibitory effect on soft rock softening, and the order of inhibition was $\mathrm{Ca}^{2+}>\mathrm{Mg}^{2+}>\mathrm{Na}^{+}$. According to the inhibitory effect of ions on soft rock softening, we propose that seawater or calcium salt should be added to reduce the softening of soft rock in soft rock engineering and improve the mechanical strength of soft rock; in addition, soft rock can be considered a raw material in marine engineering. The experimental results have great significance for studies of the disintegration mechanism and inhibitory rules of soft rock under the influence of seawater and provide a theoretical basis for the application of soft rock in marine engineering, such as in artificial reef engineering and coastal dike engineering.
\end{abstract}

Keywords: red-bed soft rock; seawater; ion; softening mechanism; control

\section{Introduction}

In recent years, with the construction of man-made islands and reefs, maritime airports, undersea tunnels, undersea military bases and other marine projects, marine engineering has entered an era of great advancements. In engineering construction, a large amount of geotechnical material is often needed as engineering filler. Although red rock is widely distributed in coastal areas, red rock layers easily soften and collapse in water, and so, in red rock distribution areas, especially coastal areas, the widely distributed soft rock. Alternatively, inland granite, basalt and other geotechnical materials are chosen as engineering raw materials, resulting in high transportation and time costs. Large amounts of manpower and material and considerable financial resources are consumed, and the protection of the natural ecological environment and sustainable development will also be greatly impacted. However, 
if soft rock and local materials can be used according to local conditions, project costs will be greatly reduced, and the impact on the natural environment will be minimized to the greatest extent. Therefore, for the widely distributed red-bed soft rock, an application objective in marine engineering is to solve the problems of softening and disintegrating under seawater conditions. In the past, research on soft rock softening control has mainly focused on soft rock modification experiments [1-13] and soft rock deformation control methods [14-24]. In general, durability characteristics are tested prior to design in seawater conditions. Through theoretical research, e.g., Li et al. [9,10], the feasibility of modifying soft rock by electrochemistry has been assessed according to the physical, chemical and mechanical properties of the soft rock itself. Two mechanisms of the electrochemical modification of clay minerals are reviewed: the stability mechanism of electroosmotic dehydration and cation substitution and the mechanism of structural and property changes. Liu et al. [5] selected a salt solution as the hydrolysate to conduct collapse resistance tests of red sandstone and proposed that the improvement by mixing with 7\% lime is the best engineering measure to restrain the collapse of class I red sandstone. Liu [11] studied the effect of the solution concentration on the expansion and deformation of mudstone. A KCl solution effectively inhibited the expansion and deformation of reconstructed mudstone samples. Yang et al. [12] used chemical modification, cement modification and composite modification to change the structure of soft rock from a microscopic point of view and found that composite modification can form a hydrophobic film on the surface of rock particles. Furthermore, the cementation force between particles was improved. In addition to indoor modification tests of soft rock, scholars have performed road use research on soft rock [25-29]. These studies provide a solid theoretical basis for the control of soft rock softening. If soft rock softening control methods can be used in marine engineering construction, it will greatly aid marine engineering involving soft rock.

Research on the deformation control of soft rock mainly focuses on the failure mechanism and deformation control of soft rock roadways. Numerical experiments such as those by Wang et al. [14] are carried out on the basis of considering the arch strength, ground stress, mechanical parameters of the surrounding rock, deformation of the surrounding rock, range of the plastic zone and the mechanical properties of the supporting unit by comparing and analyzing different factors. Thus, the failure and control mechanisms of deep soft rock roadways are determined. Yuan et al. [15] revealed the compound failure mechanism of a Mesozoic soft rock roadway in the Shajihai mining area, which involved the molecular expansion, shear slip and structural disturbance of the weak structural surface, and proposed coupling support technology with large-deformation constant bolt resistance as the core. Li et al. [21] proposed that the instability mechanism of soft rock roadways caused by a high content of confined water consists of fracturing, seepage, silting and closing processes based on two experimental cycles of the surrounding rock; these processes decrease rock strength and lead to roadway instability. However, at present, experimental studies on soft rock softening control under seawater conditions are still limited to the damage characteristics and stability analysis stage of coastal rock bank slopes [30-35].

Therefore, this paper takes sandy mudstone as the research object, and saturated tests of soft rock under seawater conditions are performed to study the evolution of the soft rock strength under the influence of seawater and the variation in the main cations in solution during the softening process of soft rock; in addition, the characteristics of composition change, deformation and failure of the soft rock are examined. The main cations are studied, and the effects of the different ions on soft rock softening are examined. Based on the results, the softening mechanism and the softening control method of soft rock under seawater conditions are expounded. The study provides experimental and theoretical bases for the study of the effective utilization of soft rock in marine engineering. 


\section{Soft Rock Softening Test}

\subsection{Softening Test of Soft Rock under Seawater Conditions}

\subsubsection{Purpose of the Test}

The purpose of this experiment is to study the macroscopic and microcosmic variations in red-bed soft rock under seawater conditions and to examine the inhibitory mechanism of seawater on soft rock softening.

\subsubsection{Test Content and Process}

The sandy mudstone widely distributed in South China is selected as the research object. The geologic age of the red sandy mudstone we used is the cretaceous period. The main minerals of the sandy mudstone are quartz, calcite, anorthite, tremolite and clay minerals. In this experiment, the sandy mudstone was made into standard $50 \times 100 \mathrm{~mm}$ cylinders. The element composition of three selected rock samples is determined via scanning electron microscopy, the energy spectrum and the electron backscattering diffraction system in a thermal field emission environment. According to the energy spectrum, the contents of $\mathrm{C}, \mathrm{O}, \mathrm{K}, \mathrm{Al}, \mathrm{Fe}, \mathrm{Si}$ and other elements are measured for the three samples of natural soft rock. Table 1 provides the percentage of elements in each rock sample. The sum of the Si and Ca contents in the three rock samples is approximately $90 \%$.

Table 1. Relative content percentage of elements in the rock samples.

\begin{tabular}{ccccccccc}
\hline \multirow{2}{*}{ Sample Label } & \multicolumn{8}{c}{ Relative Content Percentage of Each Element (\%) } \\
\cline { 2 - 9 } & C & O & Mg & Al & Si & K & Ca & Fe \\
\hline 01 & 11.79 & 48.46 & 0.52 & 5.01 & 21.21 & 2.51 & 7.85 & 2.66 \\
02 & 13.73 & 49.33 & 0.37 & 3.43 & 16.24 & 1.49 & 14.44 & 0.96 \\
03 & 12.89 & 49.54 & - & 1.81 & 13.91 & 1.06 & 20.15 & 0.64 \\
\hline
\end{tabular}

The test process mainly includes the following:

(1) The rock samples were immersed in two kinds of soaking solutions for 30 days. The $\mathrm{pH}$ value and main cationic concentration of the solution were measured in the first 7 days, and the $\mathrm{pH}$ value was measured every $12 \mathrm{~h}$, while the ion concentration was measured every $24 \mathrm{~h}$.

(2) During the initial $24 \mathrm{~h}$ of soaking, macroscopic changes in the soft rock were observed at intervals of $1 \mathrm{~h}$, and the fracture development and disintegration were recorded.

(3) A uniaxial compressive strength test was carried out on the natural rock samples after 30 days of immersion.

\subsection{Inhibition Testing of the Ions on Soft Rock Softening}

\subsubsection{Testing Programme}

The concentrations of the four main cations in seawater are in the order of $\mathrm{Na}^{+}>\mathrm{Mg}^{2+}>\mathrm{Ca}^{2+}>$ $\mathrm{K}^{+}$, and so $\mathrm{MgCl}_{2}, \mathrm{CaCl}_{2}$ and $\mathrm{NaCl}$ are selected as the dissolved salts in the experiments, and $\mathrm{K}^{+}$is not considered in the experiments.

The experiments consisted of observing the effects of $\mathrm{MgCl}_{2}, \mathrm{CaCl}_{2}$ and $\mathrm{NaCl}$ solutions with two different concentrations of $0.1 \mathrm{~mol} / \mathrm{L}$ and $1 \mathrm{~mol} / \mathrm{L}$ on soft rock softening and to examine the inhibitory effect of the different ions and ion concentrations on soft rock softening.

Because it is difficult to maintain complete consistency in sample concentration and solute solubility in the experiments, the following assumptions are made: 
(1) After preparation of the solution was completed and maintaining the solution for $30 \mathrm{~min}$, the initial concentration of the solution remained constant, and it was assumed that there was no solute precipitation.

(2) After each sampling, it is assumed that the concentration of the solution remains consistent before and after sampling and does not change with the change in volume.

\subsubsection{Test Process}

The ion variations in each ionic solution were measured every $24 \mathrm{~h}$ for 7 days, and the softening coefficient of the rock samples after 30 days of immersion was calculated. Then, the inhibitory influences of the ions on soft rock softening were compared and analysed.

\section{Softening Law of Soft Rock under Seawater Conditions}

\subsection{Effect of Seawater on Soft Rock Softening}

\subsubsection{Macroscopic Variation Law of the Rock}

Figure 1 shows the macroscopic changes in the soft rock after soaking for $2 \mathrm{~h}, 6 \mathrm{~h}$ and $18 \mathrm{~h}$.

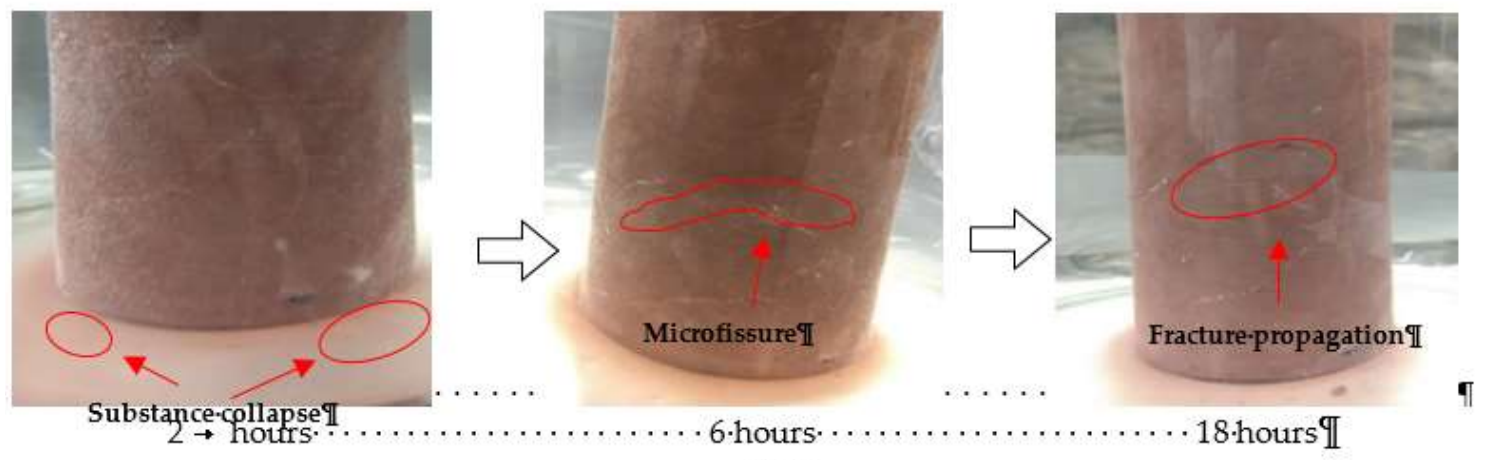

(a) $\mathbb{1}$

\section{II}

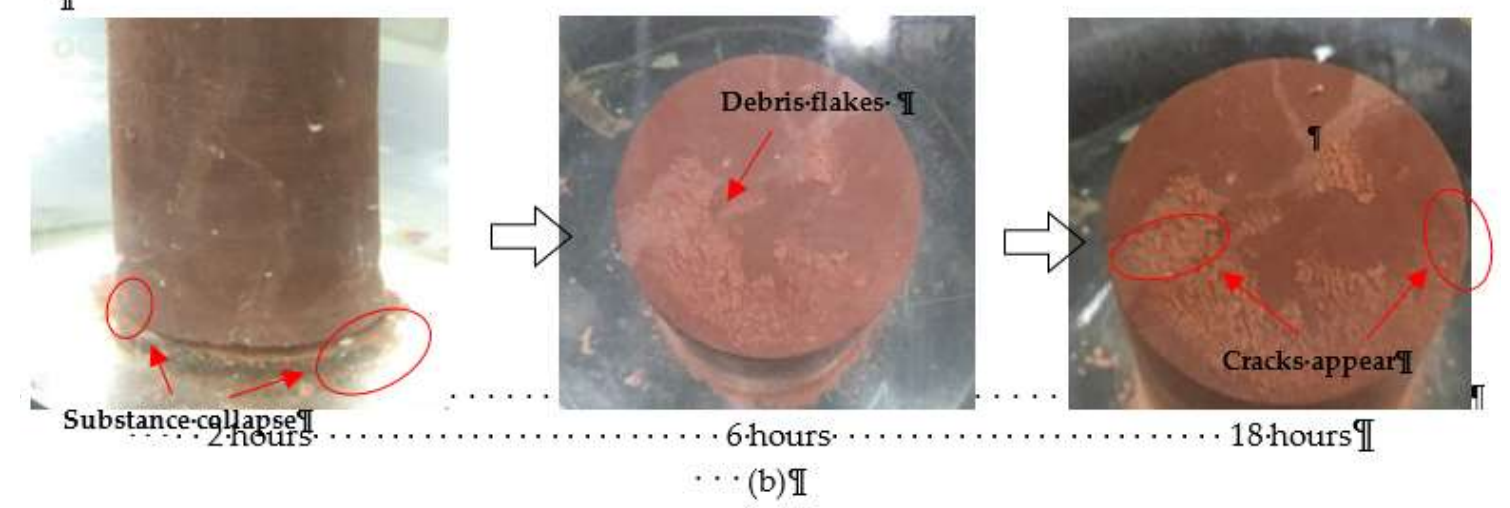

Figure 1. The softening process of soft rock over time under pure water and seawater conditions: (a) Pure water immersion; (b) Seawater immersion.

After considering and referring to some standard test methods [36-38], the macroscopic changes in the soft rock softened in seawater and pure water are compared, and when the rock sample is immersed for $2 \mathrm{~h}$, the rock sample clearly collapses, and soft rock-caving occurs at the bottom of beaker. Fine debris particles are observed in the seawater, but in pure water, powder is observed. After soaking for $6 \mathrm{~h}$, there are distinct cracks on the surface of the soft rock immersed in pure water, while in seawater, debris flakes can easily be seen on the surface of the soft rock, but there are no cracks on the surface of the soft rock. 
With the progress of softening and disintegration, the cracks on the surface of the soft rock in pure water gradually expand. After $18 \mathrm{~h}$, cracks appeared on the upper surface of the soft rock in seawater, while the cracks in pure water were more developed. From these observations, it can be deduced that the soft rock softening rate is higher, the water-rock interactions are stronger, and the degree of disintegration is higher in pure water.

\subsubsection{Change in the Ion Concentration}

The largest concentration changes in $\mathrm{Ca}^{2+}, \mathrm{Mg}^{2+}, \mathrm{Na}^{+}$and $\mathrm{K}^{+}$are mainly determined. The concentration curves of the ions with time are shown in Figures 2 and 3.

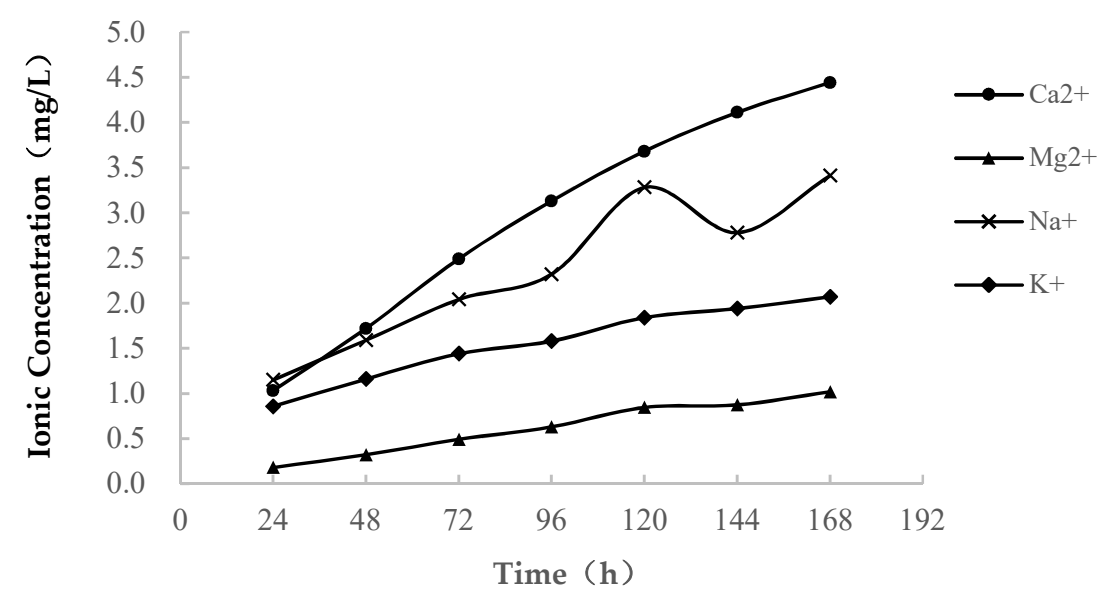

Figure 2. Concentration change curves of the main cations after pure water immersion.

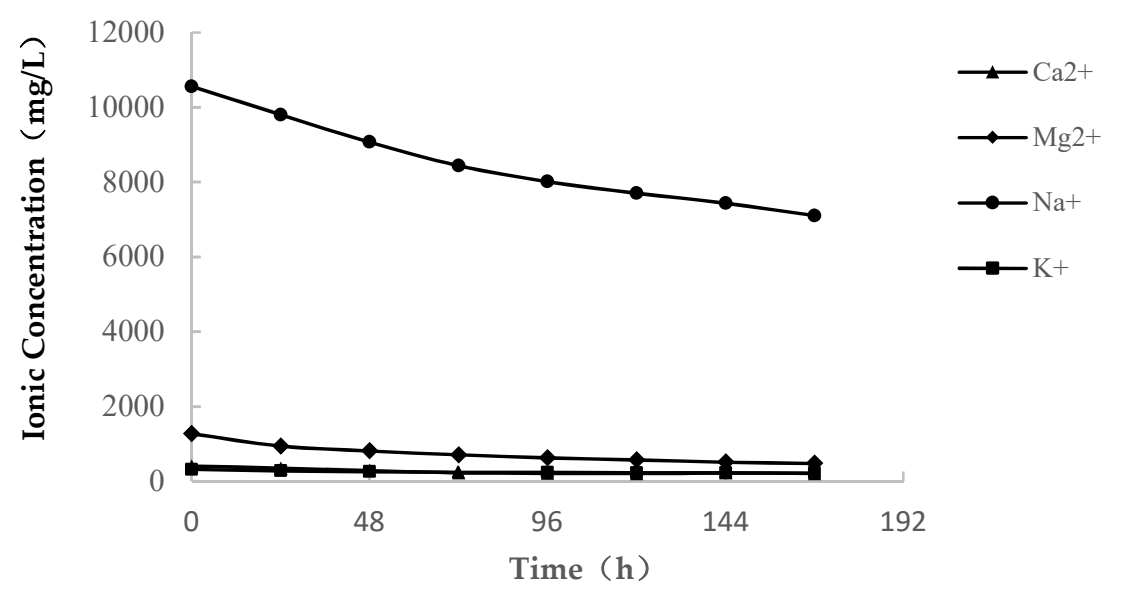

Figure 3. Concentration change curves of the main cations after seawater immersion.

The curves show that the change in cationic concentration of the aqueous solution during sample saturated with water has the following characteristics:

(1) In pure water immersion, the dissolution of soft rock is very strong, large amounts of $\mathrm{Ca}^{2+}, \mathrm{Mg}^{2+}$, $\mathrm{Na}^{+}$and $\mathrm{K}^{+}$are ionized, and the concentration of each ion increases. These ions are the main components of soluble minerals, which are often present in the ionic state in solutions. When sample immersion lasts approximately $120 \mathrm{~h}$, the dissolution of minerals gradually weakens, the upward trend of the ion concentration slows down, and ion exchange increases.

(2) In seawater immersion, there are high concentrations of $\mathrm{Ca}^{2+}, \mathrm{Mg}^{2+}, \mathrm{Na}^{+}$and $\mathrm{K}^{+}$in the initial solution. With the process of softening, the cations are continuously consumed under the actions of water and rock, and the ion concentration decreases gradually. When the initial solution 
reaches a certain saturated state, the softened soft rock tends to be stable, and the concentration of metal cations in the solution remained stable.

(3) Through the variation curve of the cationic concentration of the solution during the soft rock saturated with water, it is found that the concentrations of $\mathrm{Ca}^{2+}, \mathrm{Mg}^{2+}, \mathrm{Na}^{+}$and $\mathrm{K}^{+}$change greatly, which indicates that the softening and disintegration of soft rock in seawater may be related to the change in the main ion content in seawater.

\subsubsection{Uniaxial Compressive Strength Test}

With reference to the relevant experimental standards [17,39], it is difficult to sample and conduct testing, but good results are obtained with respect to sampling success rate and disturbance resistance with self-made sampling equipment. The uniaxial compressive strength of the soft rock samples and the natural state of the soft rock samples soaked for 30 days under the two water conditions are tested. The results are provided below (see Table 2).

Table 2. The uniaxial compressive strength of the soft rock in three states.

\begin{tabular}{cccc}
\hline Content & \multicolumn{3}{c}{ Compressive Strength (MPa) } \\
\cline { 2 - 4 } Group & I & II & Average Value \\
\hline Natural & 25.8 & 26.7 & 26.25 \\
Pure Water & 10.02 & 10.21 & 10.12 \\
Seawater & 13.36 & 13.97 & 13.67 \\
\hline
\end{tabular}

The experimental results (see Figure 4) show that the uniaxial compressive strength of the rock samples immersed in pure water and seawater decreases notably, which indicates that the overall strength of soft rock decreases after water-saturated. At the same time, according to the experimental results, the uniaxial compressive strength of the soft rock in seawater is $13.67 \mathrm{MPa}$, which is higher than that of the rock sample in pure water (10.12 MPa). From the shape variable, it can be concluded that, in the natural state, the strain of the rock sample at the time of failure is greater than that after water-saturated.

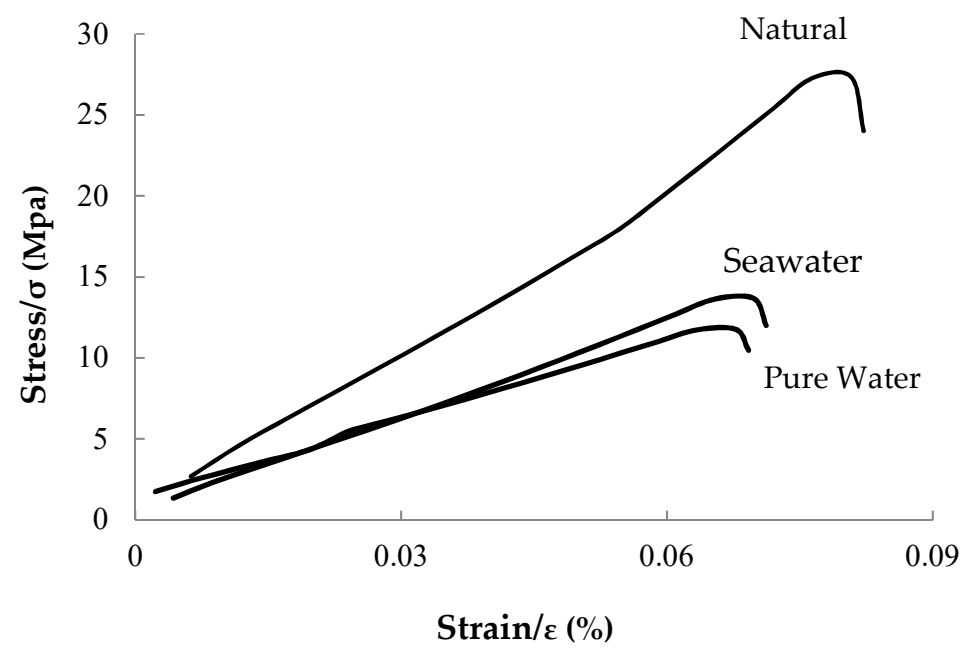

Figure 4. Stress-strain diagram of the three states.

Because the whole test process is conducted under still indoor water conditions, the influences of other physical factors are excluded, and the results of the collapse and strength tests of the soft rock under pure water and seawater conditions are compared and analysed. It is considered that a series of physical and chemical reactions have taken place between the main cations and the soft rock in seawater under the actions of water and rock, which has suppressed soft rock softening. 
3.2. Inhibitory Influences of the Ions on the Softening of Soft Rock

\subsubsection{Variations in Ion Concentration}

Due to the large concentration difference between the different ions, the data are incrementally processed based on the initial values.

That is, the increment is

$$
\Delta=\mathrm{N}_{t=i}-\mathrm{N}_{t=0}
$$

where $\mathrm{N}_{t=i}$ denotes the solute ion concentration and $\mathrm{N}_{t=0}$ represents the initial ion concentration.

The ion increment curves of the three solutions with concentrations of $0.1 \mathrm{~mol} / \mathrm{L}$ and $1 \mathrm{~mol} / \mathrm{L}$, are shown in Figures 5 and 6, respectively.

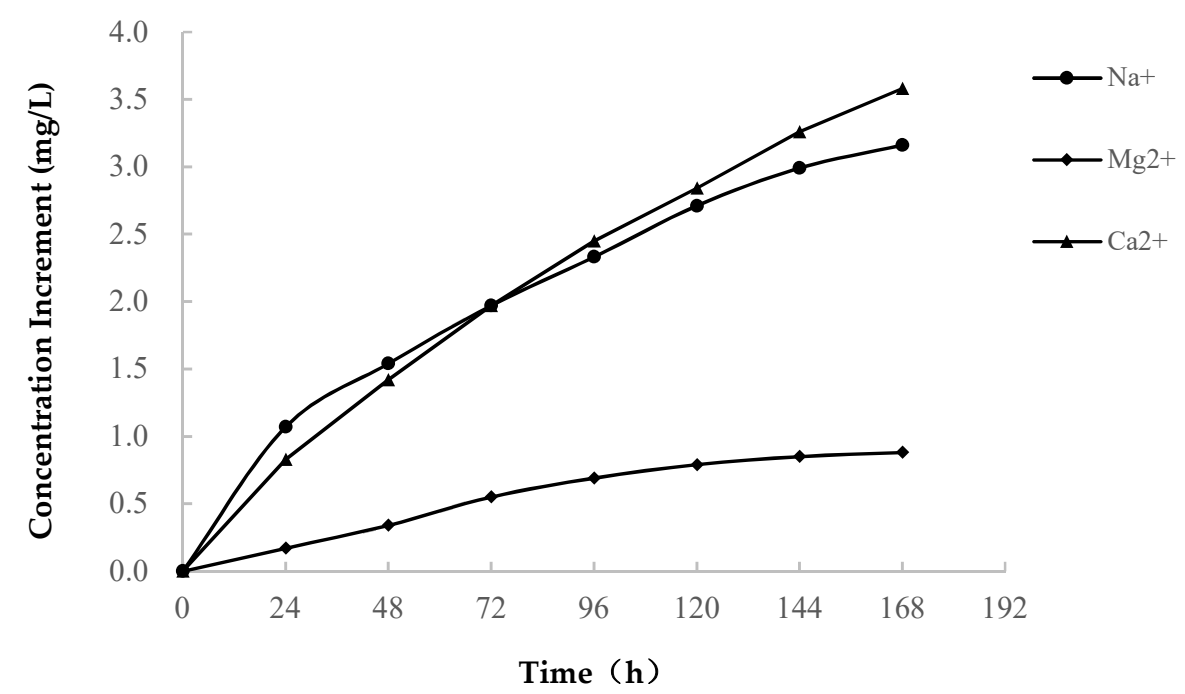

Figure 5. The change curve of the ion concentration in each $0.1 \mathrm{~mol} / \mathrm{L}$ solution.

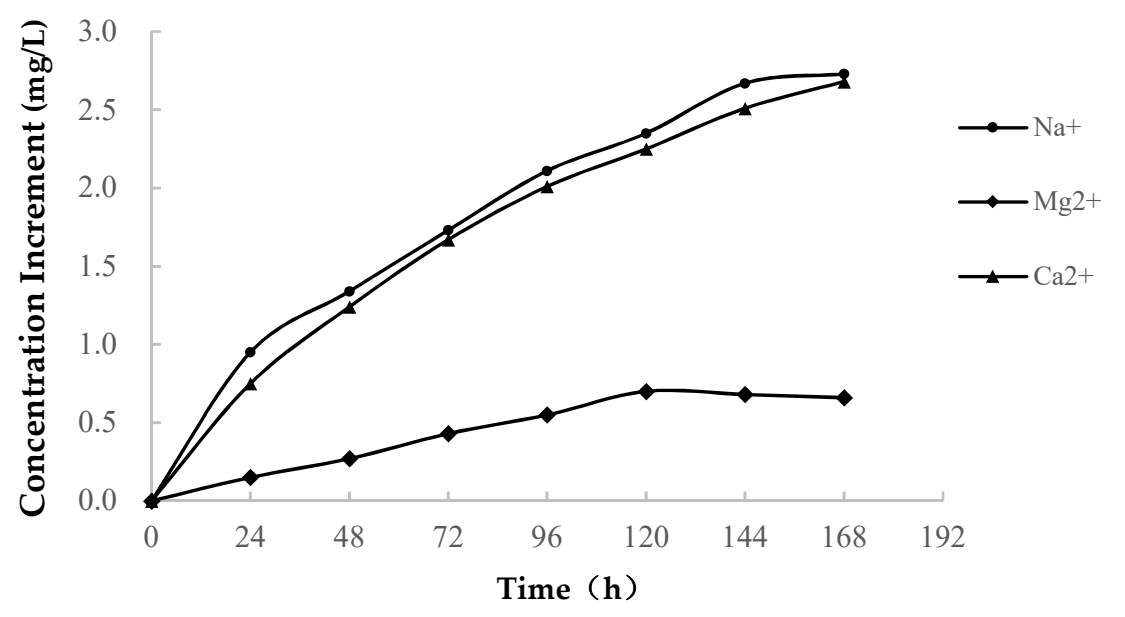

Figure 6. The change curve of the ion concentration in each $1 \mathrm{~mol} / \mathrm{L}$ solution.

As shown in Figures 5 and 6, the growth rates of the $\mathrm{Na}^{+}$and $\mathrm{Ca}^{2+}$ concentrations are basically consistent, but the growth rate of $\mathrm{Mg}^{2+}$ is lower than those of the first two ions. The author proposes the following two reasons:

(1) As shown in Table 1, Ca is the main component of soft rock, which occurs in the calcareous cement that connects the clay particles. When the soft rock encounters water, the soluble calcareous cement dissolves. The concentration of $\mathrm{Ca}^{2+}$ increases at a high rate in the early stage of softening. 
The rapid increase in the $\mathrm{Na}^{+}$concentration is related to the dissolution of soluble minerals, and it is possible that albite dissolves and $\mathrm{Na}^{+}$precipitates.

$$
2 \mathrm{NaAlSi}_{3} \mathrm{O}_{8}+9 \mathrm{H}_{2} \mathrm{O}+2 \mathrm{H}^{+} \leftrightarrow \mathrm{Al}_{2} \mathrm{Si}_{2} \mathrm{O}_{5}(\mathrm{OH})_{4}+4 \mathrm{H}_{4} \mathrm{SiO}_{4}+2 \mathrm{Na}^{+}
$$

(Dissolution of albite)

(2) In the $\mathrm{MgCl}_{2}$ solution, the lattice substitution of $\mathrm{Mg}^{2+}$ is limited to the montmorillonite structure, and the negative charge formed after substitution is compensated by $\mathrm{Na}^{+}$and $\mathrm{Ca}^{2+}$. In the $\mathrm{NaCl}$ and $\mathrm{CaCl}_{2}$ solutions, the amounts of $\mathrm{Na}^{+}$and $\mathrm{Ca}^{2+}$ consumed to compensate the negative charges are smaller than that of $\mathrm{Mg}^{2+}$ consumed by substitution. Moreover, the $\mathrm{Mg}$ content in soft rock is low, and the amount of $\mathrm{Mg}^{2+}$ formed by the dissolution reaction is also low.

For the above two reasons, the concentration of $\mathrm{Mg}^{2+}$ is lower than those of $\mathrm{Na}^{+}$and $\mathrm{Ca}^{2+}$. In addition, the ion concentration variations for different concentrations of the same ionic solution are plotted in Figures 7-9.

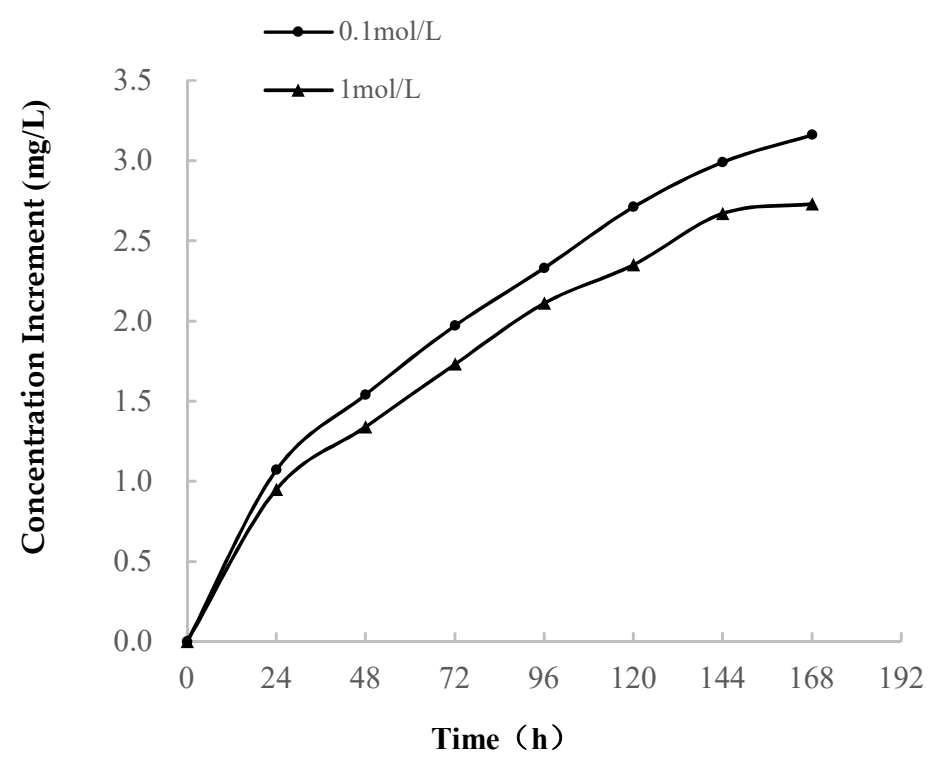

Figure 7. The $\mathrm{Na}^{+}$concentration increase curve for the $\mathrm{NaCl}$ solution.

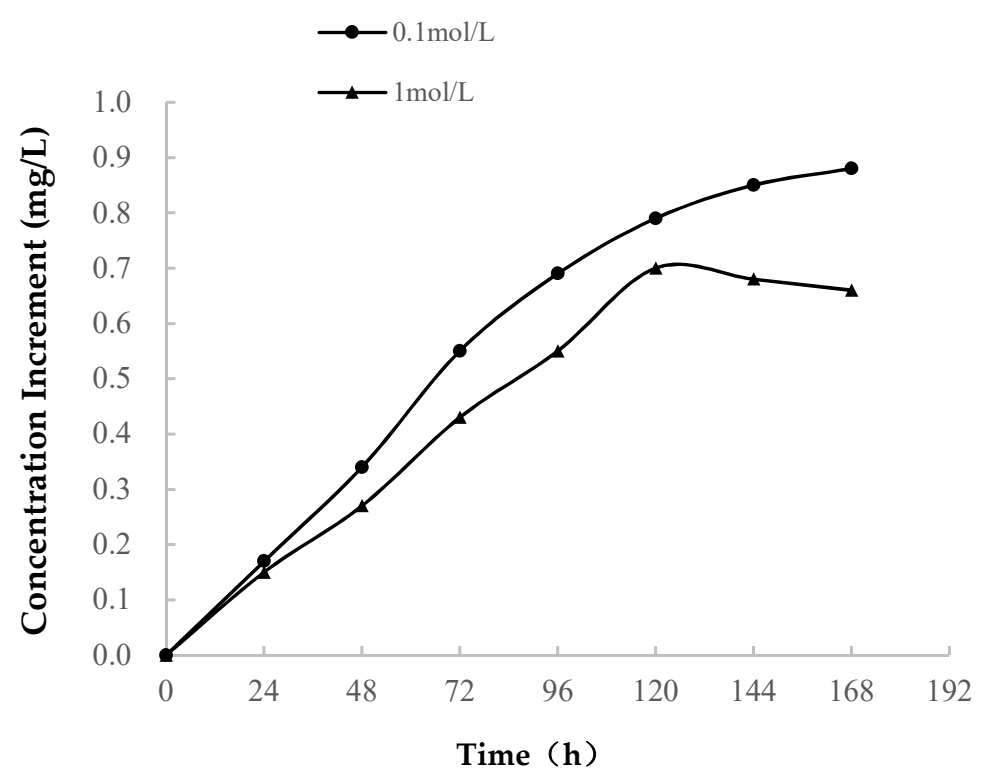

Figure 8. The $\mathrm{Mg}^{2+}$ concentration increase curve for the $\mathrm{MgCl}_{2}$ solution. 


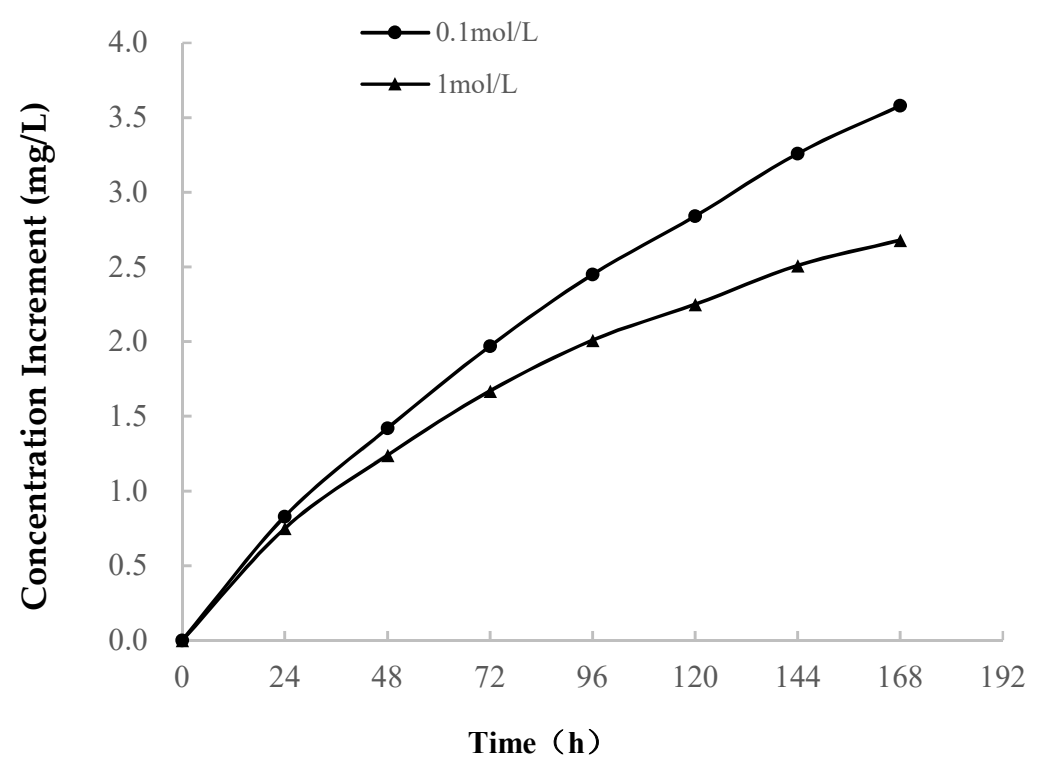

Figure 9. The $\mathrm{Ca}^{2+}$ concentration increase curve for the $\mathrm{CaCl}_{2}$ solution.

According to the ion concentration increment curve for each solution, the increase in ion concentration gradually slows with time and tends to stabilize or even decrease, as shown in Figure 8 for example. In the $1 \mathrm{~mol} / \mathrm{L} \mathrm{MgCl}$ solution, when the softening time reached $120 \mathrm{~h}$, the concentration of $\mathrm{Mg}^{2+}$ stopped increasing; on the contrary, there was a small decrease. It can be considered that in the beginning, the soft rock is softened mainly by the dissolution of soluble minerals, and the $\mathrm{Mg}$ minerals in the soft rock dissolve by the solution to form $\mathrm{Mg}^{2+}$. When rock softening has proceeded for approximately $120 \mathrm{~h}$, the soluble minerals on the surface of the soft rock are almost completely dissolved. As a result, dissolution decreases, but the exchange of adsorbed ions is enhanced, and lattice replacement consumes the free $\mathrm{Mg}^{2+}$, which reduces the concentration of $\mathrm{Mg}^{2+}$ in the solution; hence, there is a small decrease in the concentration. Because of the continuous actions of water and rock, mineral dissolution and ion exchange-adsorption always occur at the same time, so it can be predicted that the concentration of $\mathrm{Mg}^{2+}$ will be in a dynamic equilibrium state in the continued softening process, but will eventually stabilize.

\subsubsection{Analysis of the Softening Coefficient}

The evaluation of the mechanical properties of soft rock is mainly characterized by the softening coefficient. The rock-softening coefficient refers to the ratio of the uniaxial compressive strength when the rock is saturated to the compressive strength in the dry state, which is represented by $\eta$. Because the compressive strength of rock after saturated with water is lower than that in the dry state, the softening coefficient is generally less than 1 , and the expression is as follows:

$$
\eta=\frac{R_{s}}{R_{d}}
$$

where $R_{\mathrm{s}}$ denotes the average uniaxial compressive strength in the saturated state and $R_{\mathrm{d}}$ denotes the average uniaxial compressive strength in the dry state.

After 30 days of immersion, uniaxial compression tests were carried out on the three groups of soft rocks, and the results are shown in Table 3 below. 
Table 3. Uniaxial compressive strength comparison table.

\begin{tabular}{|c|c|c|}
\hline \multirow{2}{*}{$\begin{array}{l}\text { Concentration } \\
\text { Solution } \\
\end{array}$} & \multicolumn{2}{|c|}{ Compressive Strength (MPa) } \\
\hline & $0.1 \mathrm{~mol} / \mathrm{L}$ & $1 \mathrm{~mol} / \mathrm{L}$ \\
\hline $\mathrm{NaCl}$ & 11.68 & 13.47 \\
\hline $\mathrm{CaCl}_{2}$ & 13.67 & 17.38 \\
\hline $\mathrm{MgCl}_{2}$ & 12.86 & 15.47 \\
\hline
\end{tabular}

The experimental results (see Table 4) show that the saturated uniaxial compressive strength of soft rock in the $1 \mathrm{~mol} / \mathrm{L}$ solution is clearly higher than that in the $0.1 \mathrm{~mol} / \mathrm{L}$ solution. For the different solutions with the same concentration, the saturated uniaxial compressive strength of the soft rock in the $\mathrm{CaCl}_{2}$ solution is higher than that in the $\mathrm{MgCl}_{2}$ solution, and that in the $\mathrm{MgCl}_{2}$ solution is higher than that in the $\mathrm{NaCl}$ solution, but the uniaxial compressive strength of these groups of soft rock is higher than that of the soft rock in pure water to a certain extent. This phenomenon shows that the $\mathrm{CaCl}_{2}$ solution maintains the strength of soft rock to a certain extent, followed by the $\mathrm{MgCl}_{2}$ and $\mathrm{NaCl}$ solutions.

Table 4. Softening coefficient comparison table.

\begin{tabular}{|c|c|c|}
\hline \multirow{2}{*}{$\begin{array}{l}\text { Concentration } \\
\text { Solution }\end{array}$} & \multicolumn{2}{|c|}{ Softening Coefficient } \\
\hline & $0.1 \mathrm{~mol} / \mathrm{L}$ & $1 \mathrm{~mol} / \mathrm{L}$ \\
\hline $\mathrm{NaCl}$ & 0.44 & 0.46 \\
\hline $\mathrm{CaCl}_{2}$ & 0.52 & 0.58 \\
\hline $\mathrm{MgCl}_{2}$ & 0.49 & 0.51 \\
\hline
\end{tabular}

According to the above analysis and the softening coefficients, it can be concluded that the order of the ionic inhibitory effect on soft rock is $\mathrm{Ca}^{2+}>\mathrm{Mg}^{2+}>\mathrm{Na}^{+}$, and the higher the ion solubility is, the more notable the softening effect on soft rock is.

Through regular analysis, the ionic inhibition on soft rock softening may be related to the following influencing factors of ion exchange-adsorption:

(1) $\mathrm{Ca}^{2+}$ and $\mathrm{Mg}^{2+}$ are bivalent cations. In the lattice substitution of montmorillonite and kaolinite, the exchange capacity of divalent ions is greater than that of the monovalent $\mathrm{Na}^{+}$.

(2) According to the influence of the ion radius on the exchange capacity, because the order of the ion radius is $\mathrm{Ca}^{2+}>\mathrm{Mg}^{2+}>\mathrm{Na}^{+}$, the order of the ion exchange capacity is $\mathrm{Ca}^{2+}>\mathrm{Mg}^{2+}>\mathrm{Na}^{+}$.

(3) In the three solutions, the higher the concentration of the ionic solution is, the more soft rock softening is inhibited.

\section{Softening Mechanism of Soft Rock under Seawater Conditions}

According to the experimental analysis and the characteristics of clay minerals, the softening mechanism of soft rock under seawater conditions includes the following processes: water absorption, expansion and disintegration of clay minerals, ion exchange-adsorption, and dissolution of soluble minerals.

\subsection{Mechanism of Water Absorption, Expansion and Disintegration of the Clay Minerals}

(1) Because kaolinite, Illite and other clay minerals have small particles and are strongly hydrophilic, when interacting with seawater, the water molecules enter the layered clay mineral particles and form polarized water molecular layers between the particles. These water molecular layers can continuously absorb water and expand, resulting in an increasing gap between the particles. At the same time, water molecules enter the unit cell interlayers of the clay minerals, forming an interlayer water layer in the minerals. Relatively speaking, it is easier for water molecules 
to enter the interparticle gap than to enter the interlayer of each particle. The former causes the external expansion of clay minerals, called intragranular expansion, and the latter causes internal expansion, called intra-particle expansion. Existing studies [40] show that the physical and chemical reactions between Illite and water can cause the expansion of soft rock, which can increase the original volume by $50 \%$ to $60 \%$. The chemical reaction process is as follows:

$$
\mathrm{K}_{0.9} \mathrm{Al}_{2.9} \mathrm{Si}_{3.1} \mathrm{O}_{10}(\mathrm{OH})_{2}+\mathrm{nH}_{2} \mathrm{O} \rightarrow \mathrm{K}_{0.9} \mathrm{Al}_{2.9} \mathrm{Si}_{3.1} \mathrm{O}_{10}(\mathrm{OH})_{2} \cdot \mathrm{nH}_{2} \mathrm{O}
$$

(2) According to the two kinds of expansion of clay minerals, the clay particles of soft rock can absorb much water during water immersion, which increases the unit cell distance or thickens the diffusion layer, and the minerals expand. When the expansion stress exceeds the bonding effect, the clay cements are destroyed and disintegrated, while the clastic particles gravitationally disintegrate due to the lost connections. In addition, due to the uneven water absorption and expansion of clay minerals, an uneven stress distribution gradually develops in the soft rock, resulting in a large number of micropores, which destroy the original internal structure of the rock sample. Finally, the phenomenon leads to the fragmentation and disintegration of rock particles.

\subsection{Ion Exchange-Adsorption}

In the early stage of the interaction between soft rock and seawater, the water-rock interactions are mainly the dissolution of soft rock and cation exchange-adsorption, and the dissolution of soluble minerals is gradually weakened and tends to be stable due to the high ion concentration in the solution.

Second, the process of ion exchange-adsorption between water and rock is affected by many factors, such as the mineral composition, structure compactness, $\mathrm{pH}$ value and chemical composition or concentration. In an environment of no energy exchange or less energy exchange with the outside world, the total charge of cations adsorbed by clay minerals remains unchanged, and most of the exchange and adsorption of ions is carried out under these conditions, and the ion exchange between water and clay minerals will reach an equilibrium. When the hydrochemical environment changes, this balance will be disturbed, so that the ions will spread rapidly in a short period of time and ion exchange and adsorption will occur again, and the structure of soft rock will also change. Therefore, when the structure of soft rock changes, clay minerals disintegrate, or physicochemical changes result in imbalanced charges, the adsorption and exchange of ions will be dynamically balanced.

Compared with pure water, seawater is equivalent to changing the external hydrochemical environment of soft rock, resulting in a residual negative charge of the clay minerals due to homomorphism, and the non-saturated negative charge between the crystal layers makes the clay particles have strong surface properties. The residual negative charge is balanced by the adsorption of cations such as $\mathrm{K}^{+}, \mathrm{Na}^{+}$, and $\mathrm{Ca}^{2+}$ from the seawater, leading to a change in the interlayer spacing, which affects the suction and repulsive force between particles and affects the physical and mechanical properties of the clay minerals.

The factors affecting ion exchange-adsorption are as follows:

(1) Ion valence number: the larger the ion valence number is, the more prone to ion exchange;

(2) Ion radius: the larger the ion radius is, the smaller the ion hydration radius is, the stronger the adsorption and exchange capacities of ions are. Usually, the order of the ion exchange capacity from weak to strong is as follows:

$$
\mathrm{Li}^{+}<\mathrm{Na}^{+}<\mathrm{K}^{+}\left(\mathrm{NH}_{4}^{+}\right)<\mathrm{Mg}^{2+}<\mathrm{Ca}^{2+}<\mathrm{Ba}^{2+}<\mathrm{Al}^{3+}<\mathrm{Fe}^{3+}<\mathrm{H}^{+}
$$

(3) Ion concentration: the higher the ion concentration is, the stronger the exchange capacity. 


\subsection{Dissolution and Corrosion of the Soluble Minerals}

In addition to macroscopic expansion and disintegration and microscopic ion exchange and adsorption, the water-rock effects can cause the dissolution or corrosion of soluble minerals, resulting in a change in the structure of the soft rock. According to the variation in the ion concentration of the soft rock before and after immersion in seawater, the variation range of active ions in the aqueous solution, such as $\mathrm{Na}^{+}, \mathrm{Ca}^{2+}, \mathrm{K}^{+}$, and $\mathrm{Mg}^{2+}$, is large. Therefore, it can be inferred that the dissolution and corrosion of minerals occur in the interaction process between soft rock and water.

The possible dissolution reactions [41,42] are as follows:

$$
2 \mathrm{KAl}_{3} \mathrm{Si}_{3} \mathrm{O}_{8}+9 \mathrm{H}_{2} \mathrm{O}+2 \mathrm{H}^{+} \leftrightarrow \mathrm{Al}_{2} \mathrm{Si}_{2} \mathrm{O}_{5}(\mathrm{OH})_{4}+4 \mathrm{H}_{4} \mathrm{SiO}_{4}+2 \mathrm{~K}^{+}
$$

(Dissolution of potash feldspar)

$$
2 \mathrm{NaAlSi}_{3} \mathrm{O}_{8}+9 \mathrm{H}_{2} \mathrm{O}+2 \mathrm{H}^{+} \leftrightarrow \mathrm{Al}_{2} \mathrm{Si}_{2} \mathrm{O}_{5}(\mathrm{OH})_{4}+4 \mathrm{H}_{4} \mathrm{SiO}_{4}+2 \mathrm{Na}^{+}
$$

(Dissolution of albite)

According to the above possible reactions, the $\mathrm{pH}$ value during soft rock softening in seawater changes as follows (Figure 3): the $\mathrm{pH}$ value increases gradually, then decreases gradually, and then remains stable. The author believes that in the early stage of soft rock saturated with water, clay minerals absorb water and expand when they are immersed in water, and soluble minerals such as potassium feldspar and albite dissolve, thereby consuming the $\mathrm{H}^{+}$in water and precipitating $\mathrm{Na}^{+}$and $\mathrm{K}^{+}$; thus, the $\mathrm{pH}$ value of the solution increases gradually in the beginning stage. When the concentrations of the $\mathrm{Na}^{+}$and $\mathrm{K}^{+}$produced by the chemical reactions are too high, the ions are adsorbed onto the interlayer surfaces of the crystal layers of clay minerals, which balances the excess negative charges, and enhances the bonding force between the layers. The dissolution or corrosion of minerals is weakened, and the precipitation of metal cations is reduced. Thus, the $\mathrm{pH}$ value of the solution decreases. When the two processes reach an equilibrium, the $\mathrm{pH}$ value in the solution will remain at a stable value, and the $\mathrm{pH}$ value of this experiment is finally maintained at approximately 7.5 7.6. The analytical results are in good agreement with the experimental results.

\section{Soft Rock Softening Control under Seawater Conditions}

\subsection{Control Principle Based on the Solubility Product Rule and Same Ion Effect}

According to the previous tests, $\mathrm{Ca}^{2+}, \mathrm{Mg}^{2+}, \mathrm{K}^{+}, \mathrm{Na}^{+}$and other main mineral ions dissolve and precipitate in the process of soft rock softening. The presence of large amounts of $\mathrm{Ca}^{2+}, \mathrm{Mg}^{2+}, \mathrm{Na}^{+}$, and $\mathrm{K}^{+}$in seawater is considered based on the solubility product rule in basic chemistry [43]. The precipitation and dissolution of any electrolyte in solution is subject to a dynamic equilibrium. The index of the dissolving capacity of a material is the solubility product constant Ksp, and Ksp is the product of the coefficient power of the ionic concentration of the saturated solution of the insoluble electrolyte at a certain temperature. For example, the ionization equilibrium of insoluble electrolyte $\mathrm{X}_{\mathrm{a}} \mathrm{Y}_{\mathrm{b}}$ is:

$$
\mathrm{X}_{\mathrm{a}} \mathrm{Y}_{\mathrm{b}}(\mathrm{s}) \rightleftharpoons \mathrm{aX} \mathrm{X}^{\mathrm{m}+}+\mathrm{bY}^{\mathrm{n}-}
$$

When the system is in equilibrium, the system obeys the law of chemical equilibrium:

$$
\left[\mathrm{X}^{\mathrm{m}+}\right]^{\mathrm{a}}\left[\mathrm{Y}^{\mathrm{n}-}\right]^{\mathrm{b}}=\mathrm{K}_{\mathrm{sp}}
$$

The product of the power of ion concentration coefficients of the insoluble electrolytes in solution is called the ion product Qi:

$$
\mathrm{Q}_{\mathrm{i}}=\mathrm{c}_{\mathrm{X}^{\mathrm{m}+}}^{\mathrm{a}}{ }^{*} \mathrm{c}^{\mathrm{b}} \mathrm{Y}^{\mathrm{n}-}
$$


(1) Qi = Ksp: the solution is a saturated solution with no precipitation occurring and has obtained dynamic equilibrium;

(2) Qi < Ksp: the solution is not saturated and there is no precipitation. If there are solids in the system, the solids will dissolve until the solution becomes saturated.

(3) Qi > Ksp: the solution is oversaturated, and the equilibrium moves to the left with increasing precipitation, while the ion concentration in the solution is reduced depending on the saturation of the solution.

According to the solubility product rule, to inhibit the dissolution of the minerals of the sandy mudstone during immersion, it is necessary to increase the concentration of dissolved ions in the solution in such a way that the ion product Qi > solubility product Ksp. Soluble electrolytes containing the same ions should be added to the solution to force the equilibrium to move to the left, which achieves the same ionic effect [44].

Therefore, based on the softening inhibition test results, because there is a large amount of free $\mathrm{Ca}^{2+}, \mathrm{Na}^{+}$and $\mathrm{Mg}^{2+}$ in the three solutions, according to the solubility product rule, the authors think that during soft rock saturated with water, the presence of metal cations in the solution suppresses the dissolution of the soluble clay minerals with the same ions. Due to the aforementioned ionic effect, the equilibrium moves to the left, the dissolution of clay minerals decreases, the structure of the soft rock is more stable, and the bonding force between the particles is more intense. The collapse resistance of soft rock is improved, and the strength remains higher. According to the same ionic effect, the inhibitory effect of each ion solution on soft rock softening in the tests can be well explained.

Previous experiments have proven that at different concentrations of the same ions, high-concentration ionic solutions have a greater inhibitory effect on soft rock softening. The same ionic effect is explained as follows. Taking the $1 \mathrm{~mol} / \mathrm{L}$ and $0.1 \mathrm{~mol} / \mathrm{L} \mathrm{CaCl}_{2}$ solutions as examples, it can be understood that solid $\mathrm{CaCl}_{2}$ can be added to the $0.1 \mathrm{~mol} / \mathrm{L} \mathrm{CaCl}_{2}$ solution under the condition that the soft rock and other external factors are consistent to increase the $\mathrm{CaCl}_{2}$ concentration of the solution to $1 \mathrm{~mol} / \mathrm{L}$. In the process of continuously increasing the $\mathrm{Ca}^{2+}$ concentration, when $\mathrm{Qi}>\mathrm{Ksp}$ is satisfied, the equilibrium moves to the left and the concentration of $\mathrm{Ca}^{2+}$ decreases through calcareous precipitation. This process promotes precipitation, suppresses the dissolution of minerals and ensures the stability of the soft rock structure. It is verified that a high-concentration ionic solution has a greater inhibitory effect on soft rock.

\subsection{Soft Rock Softening Control Method under Seawater Conditions}

According to the inhibition test of the ionic solution on the softening of red rock, the results show that high contents of $\mathrm{Na}^{+}, \mathrm{Ca}^{2+}$ and $\mathrm{Mg}^{2+}$ have a certain inhibitory effect on the softening and disintegration of soft rock in seawater, and the higher the concentration is, the more notable the inhibitory effect. In this experiment, the order of the inhibitory effect of the ions is $\mathrm{Ca}^{2+}>\mathrm{Mg}^{2+}>\mathrm{Na}^{+}$, so the control method of soft rock softening under seawater conditions can be studied from the point of view of the ions.

(1) When a project is executed in a coastal area, a certain proportion or volume of seawater can be considered a soft rock softening inhibitor, which improves the mechanical properties of the soft rock packing structure to a certain extent. For marine engineering or coastal engineering, when the engineering strength requirement is not high, soft rock can be considered as foundation filling for the project, which will greatly reduce the construction cost.

(2) In addition, when the project is executed in an inland area, a certain amount of calcium salt can be added to the soft rock packing structure, and the overall stability and mechanical properties of the soft rock can be improved by relying on the inhibitory effect of calcium ions on the softening of soft rock. 


\section{Conclusions}

In this paper, sandy mudstone is the research object, and soft rock softening tests under pure water and seawater conditions and soft rock softening inhibition tests of ionic solutions are designed and carried out, and the following conclusions are drawn:

(1) In the same external environment, seawater has a certain inhibitory effect on the softening of soft rock compared with pure water, and the inhibitory effect is related to the main cations. The order of the inhibitory effect was $\mathrm{Ca}^{2+}>\mathrm{Mg}^{2+}>\mathrm{Na}^{+}$.

(2) According to the inhibitory effect of the main cations on soft rock, calcium salt can be added to soft rock, supplemented by a cement slurry, silicone and other traditional chemical modifiers to modify the soft rock to reduce its softness and the disintegration of soft rock.

This research can provide guiding references and establishes the theoretical basis for the application of soft rock filling and softening control in marine artificial islands, reef engineering and coastal embankment engineering projects and other types of marine engineering construction projects.

Author Contributions: Conceptualization, Z.L. and C.Z.; methodology, Z.L.; software, X.H.; validation, Z.L. and J.F.; formal analysis, C.Z.; investigation, Z.L.; resources, Z.L.; data curation, X.H.; writing-original draft preparation, Z.L.; writing-review and editing, C.Z.; visualization, X.H.; supervision, C.Z.; project administration, Z.L.; funding acquisition, Z.L. and C.Z.

Funding: This research was funded by the National Key R\&D Program of China [grant numbers 2017YFC1501201, 2017YFC0804605]; the Major Program of National Natural Science Foundation of China [grant number 41530638]; the Science and Technology Planning Project of Guangdong Province, China [grant numbers 2015B090925016, 2016B010124007]; the Guangdong Province: Special Support Plan for High-Level Talents [grant number 2015TQ01Z344] and the Science and Technology Project of Guangzhou, China [grant number 201803030005].

Conflicts of Interest: The authors declare no conflict of interest.

\section{References}

1. Wang, D.; Kang, T.H.; Han, W.M.; Liu, Z.P.; Chai, Z.Y. Electrochemical modification of the porosity and zeta potential of montmorillonitic soft rock. Geomech. Eng. 2010, 2, 191-202. [CrossRef]

2. Miščević, P.; Vlastelica, G. Shear strength of weathered soft rock-proposal of test method additions. In Proceedings of the Regional Symposium of the International Society for Rock Mechanics, Leiden, The Netherlands, 10 January 2009; pp. 303-308.

3. Chai, Z.Y. Feasibility analysis of electrochemical modification of materialized soft rock. In Proceedings of the Ninth National Congress on Rock Mechanics and Engineering, Beijing, China, 2015.

4. Miščević, P.; Vlastelica, G. Durability Characterization of Marls from the Region of Dalmatia, Croatia. Geotech. Geol. Eng. 2011, 29, 771-781. [CrossRef]

5. Liu, X.M.; Xiong, L.; Zhang, L.L.; Zhao, M.H. Experimental study on collapse inhibition measures of Class I Red Sandstone. Highw. Traffic Sci. Technol. 2011, 28, 25-29.

6. Zhang, P. Study on Physical Properties and Modification Mechanism of Mudstone; Taiyuan University of Technology: Taiyuan, China, 2014.

7. Wang, L.G.; Zhang, P.; Yang, J.L.; Li, X.L. Study on modification of soft rock and its microscopic mechanism. Silic. Circ. 2015, 34, 99-105.

8. Vlastelica, G.; Miščević, P.; Štambuk Cvitanović, N. Durability of soft rocks in Eocene flysch formation (Dalmatia, Croatia). Eng. Geol. 2018, 245, 207-217. [CrossRef]

9. Li, J.S.; Wang, D.; Kang, G.X.; Kang, T.H. Mechanism and Effect of Electrochemical Modification on Physicochemical Soft Rock. Adv. Mater. Res. 2011, 415-417, 2275-2280. [CrossRef]

10. Li, J.S.; Wang, D.; Kang, T.H. Electrochemical Modification of Physicochemical Soft Rock. Energy Procedia 2012, 16, 1714-1719. [CrossRef]

11. Liu, H.O. Expansion and deformation of mudstone in different hydrochemical environments. Min. Technol. 2015, 15, 44-45.

12. Yang, J.L.; Wang, L.G.; Li, X.L.; Zhao, G.C.; Li, C. Study on water damage law and chemical modification of silty mudstone. Silic. Notif. 2016, 35, 1883-1890. 
13. Liu, B.; Wang, M. Experimental study on the mechanical modification of soft rock grouting. Coal Technol. 2014, 33, 293-306.

14. Wang, Q.; Pan, R.; Jiang, B.; Li, S.C.; He, M.C.; Sun, H.B.; Wang, L.; Qin, Q.; Yu, H.C.; Luan, Y.C. Study on failure mechanism of roadway with soft rock in deep coal mine and confined concrete support system. Eng. Fail. Anal. 2017, 81, 155-177. [CrossRef]

15. Yuan, Y.; Zhu, Y.J.; Wang, W.J.; Yu, W.J. Failure mechanism of Mesozoic soft rock roadway in Shajihai coal mine and its surrounding rock control. Int. J. Min. Sci. Technol. 2014, 24, 853-858. [CrossRef]

16. Yu, W.J.; Wang, W.J.; Chen, X.Y.; Du, S.H. Field investigations of high stress soft surrounding rocks and deformation control. J. Rock Mech. Geotech. Eng. 2015, 7, 421-433. [CrossRef]

17. Vlastelica, G.; Miščević, P.; Pavić, N. Testing the shear strength of soft rock at different stages of laboratory simulated weathering. Građevinar 2016, 68, 955-966.

18. Chen, S.M.; Wu, A.X.; Wang, Y.M.; Chen, X.; Yan, Y.F.; Ma, H.J. Study on repair control technology of soft surrounding rock roadway and its application. Eng. Fail. Anal. 2018, 92, 443-455. [CrossRef]

19. Yang, S.Q.; Chen, M.; Jing, H.W.; Chen, K.F.; Meng, B. A case study on large deformation failure mechanism of deep soft rock roadway in Xin'An coal mine, China. Eng. Geol. 2017, 217, 89-101. [CrossRef]

20. Yu, Y.; Zhu, C.K.; Chong, D.Y.; Liu, Y.; Li, S.C. Catastrophe mechanism and disaster countermeasure for soft rock roadway surrounding rock in Meihe mine. Int. J. Min. Sci. Technol. 2015, 25, 407-413. [CrossRef]

21. Li, G.C.; Jiang, Z.H.; Lv, C.X.; Huang, C.; Chen, G.; Li, M.Y. Instability mechanism and control technology of soft rock roadway affected by mining and high confined water. Int. J. Min. Sci. Technol. 2015, 25, 573-580. [CrossRef]

22. Liu, J.X. Simulating quasi-brittle failures including damage-induced softening based on the mechanism of stress redistribution. Appl. Math. Model. 2018, 55, 685-697. [CrossRef]

23. Meng, B.; Jing, H.W.; Chen, K.F.; Su, H.J. Failure mechanism and stability control of a large section of very soft roadway surrounding rock shear slip. Int. J. Min. Sci. Technol. 2013, 23, 127-134. [CrossRef]

24. Yang, X.J.; Wang, E.Y.; Wang, Y.J.; Gao, Y.B.; Wang, P. A study of the large deformation mechanism and control techniques for deep soft rock roadways. Sustainability 2018, 10, 1100. [CrossRef]

25. Liu, X.M.; Zhao, M.H.; Su, Y.H. Study on the control method of the disintegrable road of the red layer soft rock. Rock Soil Mech. 2005, 19, 111-114.

26. Hu, P.; Wang, Y.H.; Qing, Q.X. Laboratory experimental study on the characteristics of soft rock improved soil. J. Hunan Univ. Technol. 2007, 2, 96-99.

27. Li, X.H.; Yao, Q.L.; Man, J.K.; Chen, C.Q.; He, L.H. Development of fractures in soft rock surrounding a roadway and their control. Min. Sci. Technol. 2011, 21, 573-579. [CrossRef]

28. Vakhnenko, O.O.; Vakhnenko, V.O.; Shankland, T.J. Soft-ratchet modeling of end-point memory in the nonlinear resonant response of sedimentary rocks. Phys. Rev. B 2005, 71, 174103. [CrossRef]

29. Yang, J.L.; Wang, L.G.; Li, X.L.; Zhang, P. Study on double Modification of mudstone subgrade in Open Pit Mine. J. Geotech. Eng. 2015, 37, 1469-1477.

30. Ermano, D.A.; Marcel, R.A.G.; Bas, H. Damage Characterization of Rock Slopes. J. Mar. Sci. Eng. 2019, 7, 10.

31. Marcel, R.A.G.; Ermano, D.A.; Bas, H. Statistical Analysis of the Stability of Rock Slopes. J. Mar. Sci. Eng. 2019, 7, 60 .

32. Liu, Z.; He, X.F.; Zhou, C.Y. Influence Mechanism of Different Flow Patterns on the Softening of Red-Bed Soft Rock. J. Mar. Sci. Eng. 2019, 7, 155. [CrossRef]

33. Zhou, C.Y.; Lu, Y.Q.; Liu, Z.; Zhang, L.H. An Innovative Acousto-optic-Sensing-Based Triaxial Testing System for Rocks. Rock Mech. Rock Eng. 2019. [CrossRef]

34. Zhou, C.Y.; Zhu, F.X. An elasto-plastic damage constitutive model with double yield surfaces for saturated soft rock. Int. J. Rock Mech. Min. Sci. 2010, 47, 385-395. [CrossRef]

35. Miščević, P.; Vlastelica, G. Estimation of embankment settlement caused by deterioration of soft rock grains. Bull. Eng. Geol. Environ. 2019, 78, 1843-1853. [CrossRef]

36. ASTM D4644-16; Standard Test Method for Slake Durability of Shales and Other Similar Weak Rocks; ASTM International: West Conshohocken, PA, USA, 2016.

37. Franklin, J.A.; Chandra, R. Slake-durability test. Int. J. Rock Mech. Min. Sci. 1972, 9, 325-341. [CrossRef]

38. Czerewko, M.A.; Cripps, J.C. Assessing the durability of mudrocks using the modified jar slake index test. Q. J. Eng. Geol. Hydrogeol. 2001, 34, 153-163. [CrossRef] 
39. ASTM D7012-14e1; Standard Test Methods for Compressive Strength and Elastic Moduli of Intact Rock Core Specimens under Varying States of Stress and Temperatures; ASTM International: West Conshohocken, PA, USA, 2014.

40. Wang, L.; Deng, H.; Deng, T.H.; Zhu, J.J. Experimental study on the correlation between collapse resistance and particle size of mudstone. J. Yangtze Acad. Sci. 2017, 34, 120-124.

41. Zhan, X.Y. Mineralogy and sintered brick and tile production. Brick Tile World. 2007, 01, 49-56.

42. Dixon, J.B.; Schulze, D.G. Soil Mineralogy with Environmental Applications; Soil Science Society of America, Inc.: Madison, AM, USA, 2002.

43. Cao, F.Q.; Mao, J.Y. Basic Chemistry; Nanjing Southeast University Press: Nanjing, China, 2006; pp. 71-72.

44. Xiong, L. Study on Collapse Mechanism of Red Bed Soft Rock and its Engineering Application; Hunan University: Changsha, China, 2011.

(C) 2019 by the authors. Licensee MDPI, Basel, Switzerland. This article is an open access article distributed under the terms and conditions of the Creative Commons Attribution (CC BY) license (http://creativecommons.org/licenses/by/4.0/). 